\title{
HUBUNGAN ANTARA KADAR PLASMINOGEN ACTIVATOR INHIBITOR-1 SERUM DENGAN DERAJAT KONTROL PENDERITA ASMA
}

\author{
AndiKartiniEka Yanti*, Djunardi Polopadang ${ }^{* *}$, HarunIskandar ${ }^{* *}$, ErwinArif**, \\ Muhammad Ilyas ${ }^{* *}$, Nur Ahmad Tabri**, Husaini Umar**, Andi Makbul Aman ${ }^{* * *}$, Syakib \\ Bakri $^{* * *}$, Arifin Seweng $* * * *$ \\ *Bagian Penyakit Dalam Fakultas Kedokteran Universitas Muslim Indonesia \\ * Subdivisi Pulmonologi Fakultas Kedokteran Universitas Hasanuddin \\ ***Departemen Ilmu Penyakit Dalam Fakultas Kedokteran Universitas Hasanuddin \\ ****Departemen Ilmu Biostatistik Fakultas Kesehatan Masyarakat Universitas \\ Hasanuddin
}

\begin{abstract}
Abstrak
Latar Belakang: Asma merupakan penyakit heterogen ditandai hiperrespons dan inflamasi saluran napas. Proses inflamasi pada asma erat hubungannya dengan remodelling saluran napas. Plasminogen activator inhibitor-1 (PAI-1) adalah enzim penghambat pada cascade plasminogen-plasmin sehingga menyebabkan deposisi matrix extracellular dan proses fibrosis pada remodeling jalan napas. Salah satu faktor penyebab asma tidak terkontrol dihubungkan dengan proses remodeling jalan napas. Tujuan: Menilai hubungan antara kadar PAI-1 serum dengan derajat kontrol penderita asma. Metode: Penelitian observational ini menggunakan metode rancangan potong lintang, dilaksanakan pada bulan April-Juni 2016 di RSUP Dr. Wahidin Sudirohusodo dan RS Universitas Hasanuddin, pada penderita asma dengan umur $>18$ tahun, bukan perokok dan tidak menderita infeksi paru. Kadar PAI-1 diperiksa dengan metode teknik enzyme linked immune sorbent assay, dan metode analisa statistik menggunakan SPSS versi 22. Derajat kontrol asma dinilai menggunakan modifikasi kriteria GINA 2015. Hasil: Sebanyak 47 subyek asma yang diperiksa, berumur 20-74 tahun, perempuan lebih banyak dibanding lakilaki (70,2\% vs 29,8\%),76,6\% subyek non-obes, dan 53,2\% menderita asma tidak terkontrol. Didapatkan rentang kadar PAI-1 serum yaitu $0,95-33,39 \mathrm{U} / \mathrm{mL}$ dengan rerata 5,73 $\pm 5,75$. Pada subyek dengan asma tidak terkontrol, rerata kadar PAI-1 serum signifikan lebih tinggi dibanding asma terkontrol $(\mathrm{p}=0,003)$. Berdasarkan umur, subyek yang $<50$ tahun dengan derajat asma tidak terkontrol, rerata kadar PAI-1 serum signifikan lebih tinggi dibanding asma terkontrol $(\mathrm{p}=0,007)$. Subjek obese dengan asma tidak terkontrol, kadar PAI-1 lebih tinggi dibandingkan dengan subjek obese asma terkontrol, meskipun secara statistik tidak signifikan ( $p>0,05)$. Subjek non-obese dengan asma tidak terkontrol, kadar PAI-1 signifikan lebih tinggi dibandingkan subjek non-obese dengan asma terkontrol ( $\mathrm{p}=0,007)$. Kesimpulan: Kadar PAI-1 ditemukan lebih tinggi secara bermakna pada asma tidak terkontrol.
\end{abstract}

Kata Kunci: Kadar PAI-1 serum, kontrol asma 


\section{PENDAHULUAN}

Asma merupakan suatu penyakit heterogen yang biasanya ditandai dengan hiperrespons dan inflamasi jalan napas. Asma ditandai dengan adanya riwayatgejala pada saluran napas berupa mengi, sesak napas, dada terasa berat dan batuk yang intensitasnya bervariasi dari waktu kewaktu, disertai adanya keterbatasan pada aliran udara ekspirasi. Asma biasanya dicetuskan oleh aktivitas, paparan alergen, perubahan cuaca dan infeksi saluran napas yang disebabkan virus. ${ }^{1}$

Asma masih menjadi masalah kesehatan masyarakat yang serius di berbagai negara di seluruh dunia. Penderita asma di seluruh duniasaatinidiperkirakan mencapai334juta dengan prevalensi 1-18\%. Di Amerika Serikat (AS) estimasijumlahpenderitaasma25,9juta orang dengan prevalensi 8-9\%. ${ }^{2}$ Prevalensi asma di Indonesia diperkirakan 5-7\% dan di Makassar berkisar $4 \%{ }^{3}$

Asma dapat timbul pada semua usia terutama usia muda dan tidak tergantung tingkat sosial-ekonomi tertentu. Meskipun asma jarang menimbulkan kematian, penyakit ini sering menimbulkan masalah baik pada anak maupun dewasa. ${ }^{2}$ Asma dapat menyebabkan gangguan aktivitas sehari-hari dan gangguan emosi (cemas, depresi). Asma dapat bersifat ringan dan tidak mengganggu aktivitas sehari-haritetapi dapat pulabersifat menetap dan mengganggu aktivitas seharihari. ${ }^{4}$ Di Amerika Serikat, asma merupakan penyakit penyebab tersering tidak masuk kerja dengan jumlah 14,2 juta hari dalam setahun dan angka tidak masuk sekolah 10,5 juta hari dalam setahun. Frekuensi kunjungan ke unit gawat darurat di AS dalam setahun
1,75 juta dan rawat inap di rumah sakit 456 ribu. Kerugian yang diakibatkan oleh asma baik untuk biaya pengobatan maupun jumlah kehilangan hari kerja dan sekolah diperkirakan sebesar 56 miliar dollar Amerika setiap tahunnya. ${ }^{2}$

Pada asma proses tersebut berperan dalam penyembuhan dan inflamasi yang menyebabkan perubahan struktur saluran napas dan dikenal dengan remodelling. ${ }^{6}$ Pada asma terdapat saling ketergantungan antara proses inflamasi dan remodelling. Infiltrasi sel inflamasi terlibat dalam proses remodelling, juga komponen lainnya seperti extracellular matrix (ECM), membran basal retikular, matriks interstisial, fibrogenic growth factor, protease, angiotensin II, plasminogen activator inhibitor-1 (PAI-1) dan tumor growth factors (TGF- $\beta$ ).7 Studi pada hewan coba menunjukkan trauma sel epitel menghasilkan pelepasan mediator proinflamasi yang bersifat fibroproliferasi dan profibrogenic growth factors yaitu (TGF- $\beta$ ), angiotensin II, fibroblastgrowthfactor, insulin growthfactor, endothelin-1, platelet-derived growth factor serta pelepasan PAI-1 oleh sel mast yang berdampak pada remodelling. ${ }^{8}$

Plasminogen Activator Inhibitor-1 merupakan suatu glikoprotein rantai tunggal 50-kDa. ${ }^{9}$ PAI-1 adalah inhibitor dari sistem aktivasi plasminogen (PAS). ${ }^{10}$ Plasminogen dapat dikonversi ke enzim aktif, plasmin. Selanjutnya plasmin akan mendegradasi fibrin menjadi fibrin larut. ${ }^{11}$ Terdapat dua aktivator plasminogen fisiologis yaitu plasminogen aktivator tipe jaringan (tPA) dan plasminogen aktivator tipe urokinase (uPA). ${ }^{12,13}$ Pada asma terjadi inflamasi kronik dan lebih lanjut remodelling jaringan sehingga terjadi keterbatasan jalan napas 
yang lebih berat dan memperparah asma. Pada asma kronik dapat terjadi perubahan struktur jalan napas irreversibel yang ditandai dengan fibrosis subepitel, deposisi matriks ekstraseluler, hipertrofi otot polos dan hiperplasiajalan napas. ${ }^{14}$ Selinflamasiseperti sel $\mathrm{T}$, sel mast dan eosinofil berperan pada inflamasi kronik dan perubahan struktur jalan napas dengan melepaskan berbagai sitokin proinflamasi dan faktor pertumbuhan. Inflamasi kronik dapat menyebabkan kerusakan jalan napas dan memodulasi fibrogenesis. PAI-1 berperan penting dalam proses fibrosis setelah inflamasi. ${ }^{15} \mathrm{Cho} \mathrm{dkk}$, dalam penelitiannya melaporkan sel mast yang merupakan sel utama pada patogenesis asma merupakan salah satu sumber utama dari PAI-1, sejumlah besar sel mast akan menginfiltrasi saluran napas dan selanjutnya dapat mengekspresikan PAI-1. ${ }^{16,17}$ Namun menurut Savov dkk, dalam penelitiannya melaporkantidakadaketerlibatan PAI-1pada hiperrespons saluran napas dari percobaan tikus. ${ }^{18}$ Bergoran dkk, dalam tulisannya tidak menyebutkan keterlibatan PAI-1 pada remodelling asma. ${ }^{18}$

Ketidakkonsistenan dari peranan PAI1 pada fungsi paru dan derajat asma dari berbagai studi yang ada sebelumnya serta penelitian yang sama di Indonesia sepanjang penulusuran kepustakaan belum pernah dilaporkan. Hal inilah yang mendasari penelitian ini dilakukan.

\section{METODOLOGI PENELITIAN}

Jenis penelitian yang digunakan adalah penelitian dengan metode rancangan potong lintang (cross sectional). Penelitian ini dilakukan di RS Wahidin Sudirohusodo dan RS Universitas Hasanuddin (UNHAS), sejak April 2016 sampai Juni 2016. Populasi penelitian adalah subyek asma (berdasarkan kriteria GINA) memenuhi kriteria inklusi, yaitu subyek asma diatas 18 tahun, bukan perokok, tidak menderita infeksi paru, bersedia mengikuti penelitian secara sukarela setelah menerima informed consent, kemudian dilakukan pemeriksaan kadar Plasminogen Activator Inhibitor-1, menggunakan teknik sandwich atau enzyme linked immune sorbent assay (ELISA) memanfaatkan Technoclone $\mathrm{GmbH}$ $P A I-1$ kit.

\section{HASIL}

Sebanyak 47 orang pasien yang berobat di poliklinik rawat jalan maupun rawat inap di Rumah Sakit Wahidin Sudirohusodo dan Rumah Sakit Pendidikan Universitas Hasanuddin dan jejaringnya selama bulan April 2016 hingga Juni 2016 yang menjadi subyek penelitian.

\section{Karakteristik Subyek}

Subyek penelitian dengan jenis kelamin perempuan, lebih banyak dari laki-laki yaitu 70,2 \% berbanding 29,8 \%, Rentang usia pasien antara 20-74 tahun, dengan rerata 49,5 tahun, sebagian besar berusia 50-69 tahun (48,9\%). Berdasarkan IMT, sebagian besar subyek termasuk kategori Non obes $(76,6 \%)$. Sebagian besar subyek menderita asma tidak terkontrol (53,2\%). Kadar PAI-1 pada subyek penelitian mempunyai rentang antara 0,9533,39 dengan rerata 5,75 (Tabel1). 
Tabel 1. Karakteristik Subyek $(n=47)$

\begin{tabular}{|c|c|c|c|c|c|}
\hline \multicolumn{2}{|l|}{ Variabel } & $\mathbf{n}$ & $\%$ & Rentang & Rerata \pm SD \\
\hline \multirow{2}{*}{ Jenis Kelamin } & Laki-Laki & 14 & 29,8 & & \\
\hline & Perempuan & 33 & 70,2 & & \\
\hline \multirow[t]{2}{*}{ Umur } & $<50$ tahun & 20 & 42,5 & $20-74$ & $49,5 \pm 14,6$ \\
\hline & $>=50$ tahun & 27 & 57,4 & & \\
\hline \multirow[t]{2}{*}{ IMT } & Obes $^{\mathrm{b}}$ & 11 & 23,4 & $18,0-33,2$ & $22,5 \pm 3,2$ \\
\hline & Non Obes & 36 & 76,6 & & \\
\hline Derajat Kontrol & Terkontrol & 22 & 46,8 & & \\
\hline Asma & Tidak terkontrola & 25 & 53,2 & & \\
\hline
\end{tabular}

Keterangan: ${ }^{a}$ Jumlahyang tidakterkontrol hanya 3 subyek, maka digabung dengan terkontrol yang sebagian

${ }^{\mathrm{b}}$ Obes bila IMT $\geq 25,0 \mathrm{~kg} / \mathrm{m}^{2}$

\section{Hubungan Kadar PAI-1 dengan Derajat Kontrol}

Tabel 2. Kadar PAI-1 menurut Derajat Kontrol

\begin{tabular}{lcccc}
\hline \hline Derajat Kontrol & n & Mean & SD & p \\
\hline Terkontrol & 22 & 3,12 & 2,01 & 0,003 \\
Tidak terkontrol & 25 & 8,03 & 6,94 & \\
\hline \hline
\end{tabular}

Kadar PAI-1 penderita asma, signifikan lebih tinggi pada asma tidak terkontrol dibandingkan yang terkontrol yaitu 8,03 dengan 3,12 $(\mathrm{p}<0,01)$. Hal ini menunjukkan

\section{Hubungan Kadar PAI-1 menurut Derajat Kontrol dan Umur}

Tabel 3. Kadar PAI-1 dengan Derajat Kontrol dan Umur

\begin{tabular}{llcccc}
\hline Umur & Derajat Kontrol & $\mathbf{n}$ & Mean & SD & p \\
\hline \hline$<50$ tahun & Terkontrol & 12 & 2,89 & 1,66 & 0,007 \\
& Tidak terkontrol & 8 & 10,32 & 10,14 & \\
\hline$>=50$ tahun & Terkontrol & 10 & 3,40 & 2,42 & 0,093 \\
& Tidak terkontrol & $\mathbf{1 7}$ & 6,95 & 4,84 & \\
\hline \hline
\end{tabular}

Berdasarkan umur, subyek yang $<50$ tahun dengan derajat asma tidakterkontrol, reratakadarPAI-1serumsignifikanlebihtinggi dibanding asma tidak terkontrol $(10,32 \mathrm{U} / \mathrm{mL}$ vs $2,89 \mathrm{U} / \mathrm{mL}, \mathrm{p}=0,007)$. Hal ini menunjukkan adanya hubungan signifikan antara kadar PAI1 yang tinggi dengan asma tidak terkontrol. adanya hubungan signifikan antara kadar PAI1 yang tinggi dengan asma tidak terkontrol (Tabel 2).
Pada subyek dengan umur $\geq 50$ tahun, kadar PAI-1 tidak berbeda signifikan antara asma terkontrol dengan tidak terkontrol ( $p>0,05)$, namun terlihat bahwa kadar PAI-1 juga lebih tinggipada asmatidak terkontrol $(6,95 \mathrm{U} / \mathrm{mL}$ vs 3,40 U/mL). (Tabel3). 


\section{Hubungan Kadar PAI-1 dengan Derajat Kontrol dan IMT}

Tabel 4. Kadar PAI-1 menurut Derajat Kontrol dan IMT

\begin{tabular}{llcccc}
\hline \hline IMT & Derajat Kontrol & n & Mean & SD & p \\
\hline \hline Obes & Terkontrol & 2 & 3,60 & 3,37 & 0,327 \\
& Tidak terkontrol & 9 & 9,87 & 9,94 & \\
\hline Non Obes & Terkontrol & 20 & 3,07 & 1,95 & 0,007 \\
& Tidak terkontrol & $\mathbf{1 6}$ & 7,00 & 4,61 & \\
\hline \hline
\end{tabular}

Dari analisis perbandingan kadar PAI1 menurut derajat kontrol dan status gizi memperlihatkan bahwa pada subjek obes, kadar PAI-1 tidak berbeda signifikan antara asma terkontrol dengan tidak terkontrol ( $\mathrm{p}>0,05)$, namun terlihat bahwa kadar PAI-1 lebih tinggi pada asma tidak terkontrol $(9,87$ $\mathrm{U} / \mathrm{mL})$, dibandingkan asma terkontrol (3,60 $\mathrm{U} / \mathrm{mL}$ ). Pada subyek non-obes dengan derajat asmaterkontrol, reratakadarPAI-1signifikan lebih tinggi dibanding asma terkontrol (7 $\mathrm{U} / \mathrm{mL}$ vs 3,07 $\mathrm{U} / \mathrm{mL} \mathrm{p}=0,007$ ). Hasil ini menunjukkan adanya hubungan kadar PAI1 dengan IMT dalam hubungannya dengan derajat kontrol asma, dimana subyek obes tidak ditemukanadanya hubungan signifikan antara PAI-1 dengan derajat kontrol asma. (Tabel 4)

\section{DISKUSI}

Asma merupakan suatu penyakit heterogen yang biasanya ditandai dengan hiperrespons dan inflamasi jalan napas. Inflamasi kronik pada asma akan menimbulkan kerusakan jaringan yang secara fisiologis diikuti oleh proses penyembuhan yang menghasilkan perbaikan dan pergantian sel rusak dengan sel yang baru. Proses penyembuhan tersebut melibatkan regenerasi jaringan yang rusak dengan sel parenkim dan jaringan penyambung berupa skar. Pada asma proses yang berperan dalam penyembuhan dan inflamasi yang menyebabkan perubahan struktur saluran napas dikenal dengan remodelling.

Inflamasi kronik pada asma dan lebih lanjut terjadinya remodelling jaringan akan menyebabkan keterbatasan jalan napas yang lebih berat dan memperparah asma. Inflamasi kronik pada asma dapat menyebabkan kerusakan jalan napas dan akan memodulasi fibrogenesis. PAI-1 dianggap berperan penting dalam proses fibrosis setelah inflamasi. PAI-1 merupakan inhibitor utama pada tissue-type and urokinase-type plasminogen activators (tPA and uPA) yang menekan fibrinolisis. Pada penelitian prospektif telah dilaporkan peningkatan kadar PAI-1 diduga memainkan peranan yang penting pada patogenesis inflamasi kronik dan remodeling pada asma.

Penelitian ini ingin melihat hubungan antara kadar PAI-1 dengan derajat kontrol pada penderita asma.

Penelitian ini kami lakukan pada 47 subyek pasien asmayang berobat di poliklinik pulmonologi RS Wahidin Sudirohusodo Makassar dan rumah sakit jejaring Bagian Ilmu Penyakit Dalam, Universitas Hasanuddin Makassar pada bulan April hingga Juni 2016. Dari karakteristik sebaran subyek penelitian tampak bahwa subyek penelitian dengan jenis kelamin perempuan, lebih banyak dari laki-laki yaitu 70,2 \% berbanding 29,8 \%, rentang usia pasien antara 20-74 tahun, 
dengan rerata 49,5 tahun, sebagian besar berusia $>=50$ tahun $(57,4 \%)$, sebagian besar subyek termasuk kategori Non obes $(76,6 \%)$, sebagian besar subyek menderita asma tidak terkontrol (53,2\%). Kadar PAI-1 pada subyek penelitian mempunyai rentang antara $0,95 \mathrm{U} /$ $\mathrm{mL}-33,39 \mathrm{U} / \mathrm{mL}$, dengan rerata $5,75 \mathrm{U} / \mathrm{mL}$.

Penelitian dengan hasil yang berbeda didapatkan oleh Rasmussen dkk, ${ }^{19}$ yang menyimpulkan terdapat perbedaan secara bermakna penurunan fungsi paru dan reversibilitas pada kelompok lakilaki dibandingkan kelompok perempuan penderita asma. Adanya perbedaan signifikan yang kami dapatkan pada penelitian ini dimungkinkan karena adanya beberapa faktor lainyangturutmempengaruhiderajatderajat kontrol pada penderita asma selain umur dan jenis kelamin seperti lingkungan, stressor psikososial, demografi, pengobatan yang tidak efektif dan adekuat, rendahnya kepatuhan pasien, terdapatnya penyakit lain yang dapat mencentuskan terjadinya serangan asma (seperti infeksi saluran pernapasan, refluks asam lambung), serta terdapatnya faktor komorbid yang tidak kami teliti dalam studi ini.

Oemiati dkk pada tahun 2010 menyimpulkan dari 31 variabel yang dianalisis hubungannya dengan penyakit asma, hasil Riskesdas 2013 menunjukkan terdapat 10 variabel yang kuat pengaruhnya terhadap terjadinya penyakit asma yaitu: umur, pendidikan, pekerjaan, penyakit TBC, ISPA, alergi dermatitis, rhinitis, merokok, konsumsi bahan pengawet dan pelihara ternak sedang (kambing, babi, domba). Sedangkan lokasi mukim, jenis kelamin, status ekonomi, konsumsi makanan mengandung bumbu penyedap/vetsin, penggunaan bahan-bahan kimia, jarak rumah ke sumber pencemaran dalam analisis multivariate tidak mempunyai hubungan dengan penyakit asma. Variabel yang paling besar keterkaitannya dengan penyakit asma yaitu penyakit-penyakit pernafasan (TBC, ISPA, rhinitis). ${ }^{20,21}$ Selain dari prevalensi asma, awal mulai terdiagnosa asma serta lamanya asma diderita juga turut mempengaruhi derajat kontrol dan derajat obstruksi pada penderita asma. ${ }^{22}$

Pada penelitian ini ditemukan bahwa kadar PAI-1 pada penderita asma signifikan lebih tinggi pada asma tidak terkontrol dibandingkan dengan terkontrol $(\mathrm{p}<0,01)$. Hal ini menunjukkan adanya hubungan signifikan antara kadar PAI-1 yang tinggi dengan asma tidak terkontrol. Penelitian Hashimoto $\mathrm{dkk},{ }^{23}$ membuktikan terjadi peningkatan vaskularisasi (angiogenesis) di saluran napas pasien asma yang berkorelasi dengan derajat kontrol asma. Seperti yang sudah dijelaskan sebelumnya peranan PAI-1 pada proses angiogenesis yang turut bertanggung jawab pada proses remodeling. ${ }^{24}$

Oh dkk, ${ }^{25,26}$ membuktikan bahwa PAI-1 meningkatkan deposisi extracellular matrix (ECM) pada saluran napas mencit dengan asma kronis. Peningkatan dari deposisi ECM yang kemudian menyebabkan terjadinya fibrosis subepitelial pada proses remodeling saluran napas. ${ }^{[6]}$

Little dkk, ${ }^{27}$ menyimpulkan bahwa fibrosis subepitelial berhubungan dengan derajat kontrol asma, dan pada asma yang berat didapatkan peningkatan ketebalan dinding saluran napas. Lebih lanjut Liu $\mathrm{dkk},{ }^{28}$ pada tahun 2015 menunjukkan bahwa pemberian TM5275, suatu sediaan PAI-1 inhibitor dapat menekan proses fibrosis 
subepitelial saluran napas pasien asma.

Pada remodeling saluran napas pasien asma selain fibrosis subepitelial, dan angiogenesis juga terdapat hiperplasia sel goblet dan glandula mukus. Aikawa $\mathrm{dkk},{ }^{29}$ mendapatkan adanya peningkatan secara signifikan pada persen sel goblet dan akumulasi mukus pada pasien yang meninggal karena serangan asma dibandingkan pasien yang meninggal dengan non status asmatikus dan kontrol. ${ }^{6}$ Lee dkk, ${ }^{30}$ juga menunjukkan bahwa pemberian Tiplaxtinin, sebuah PAI1 inhibitor dapat menekan secara signifikan derajat hiperplasia sel goblet dan deposisi kolagen pada saluran napas tikus yang diinduksi ovalbumin (OVA).

Peranan PAI-1 pada remodeling saluran napas juga terjadi melalui proses angiogenesis. Angiogenesis merupakan aspek yang penting pada remodeling saluran napas pasien asma.. ${ }^{24} \mathrm{PAI}-1$ terlibat dalam angiogenesis dengan mengatur ekspresi dan aktivitas vascular endothelial growth factor (VEGF). VEGF merupakan faktor pertumbuhan proangiogenik yang paling penting. Jumlah sel VEGF-positif meningkat pada saluran napas penderita asma dibandingkan dengan subyek kontrol, dan bertambahnya angiogenesis mukosa asma terkait dengan ekspresi VEGF yang meningkat. ${ }^{32}$ Peningkatan kadar VEGF dan reseptornya juga ditemukan di saluran napas pasien asma. ${ }^{33}$ Penelitian Hoshino dkk ${ }^{32}$ menemukan peningkatan jumlah pembuluh darah dan pembuluh darah yang semakin besar pada pasien asma atopi ringan sampai sedang dibandingkan subyek kontrol dan berkorelasi terbalik dengan persen prediksi $\mathrm{FEV}_{1}$ yang lebih rendah pada pasien asma dibandingkan subyek kontrol..$^{32,34}$
Oh menyimpulkan bahwa PAI-1 yang sebagian besar diproduksi oleh sel mast memainkan peran yang penting pada proses remodeling saluran napas pada asma. Penelitian lebih lanjut diharapkan dapat memberikan paradigma baru tentang remodeling saluran napas dan dapat menjadi terapi target yang baru. ${ }^{25}$

Pada penelitian ini didapatkan, berdasarkan umur, subyek yang $<50$ tahun dengan derajat asma tidak terkontrol, rerata kadar PAI-1 serum signifikan lebih tinggi dibanding asma terkontrol $(10,32 \mathrm{U} / \mathrm{mL}$ vs $2,89 \mathrm{U} / \mathrm{mL}, \mathrm{p}=0,007$ ). Pada subjek dengan umur $\geq 50$ tahun, kadar PAI-1 tidak berbeda signifikan antara asma terkontrol dengan tidak terkontrol $(\mathrm{p}>0,05)$, namun terlihat bahwa kadar PAI-1 juga lebih tinggi pada asma tidak terkontrol $(6,95 \mathrm{U} / \mathrm{mL}$ vs 3,40 $\mathrm{U} / \mathrm{mL}$ ). Menurut Maurizio Margaglione dan Yamamotoa $\mathrm{K}$ et al $\mathrm{dkk}^{35,36}$, seiring bertambahnya usia diikuti dengan penurunan progresif dari sistem fibrinolitik. Sistem fibrinolitikterdiriolehspektrumyang luas dari enzim proteolitik, yang terlibat dalam banyak proses (misalnya, keseimbangan hemostatik, renovasi jaringan, invasi tumor, angiogenesis, reproduksi. Plasminogen activator inhibitor-1 (PAI-1), tidak hanya meningkat pada orang tua, tetapijuga secara signifikan ditingkatkan dalam berbagai kondisi klinis yang khas dari proses penuaan (misalnya, obesitas, resistensi insulin, stres psikososial, penurunan respon imun, meningkatkan peradangan, sclerosis pembuluh darah / remodelling).

Dari analisis perbandingan kadar PAI1 menurut derajat kontrol dan status gizi memperlihatkan bahwa pada subyek obes, kadar PAI-1 tidak berbeda signifikan antara asma terkontrol dengan tidak terkontrol 
( $\mathrm{p}>0,05)$, namun terlihat bahwa kadar PAI1 lebih tinggi pada asma tidak terkontrol (9,87 U/mL), dibandingkan asma terkontrol (3,60 U/mL). Pada subyek non-obes dengan derajat asma tidak terkontrol, rerata kadar PAI-1 signifikan lebih tinggi dibanding asma terkontrol (7 U/mL vs 3,07 U/mL, p=0,007). Hasil ini menunjukkan adanya interaksi kadar PAI-1 dengan IMT dalamhubungannya dengan derajat kontrol asma, dimana subyek obes tidak ditemukan adanya hubungan signifikan antara PAI-1 dengan derajat kontrol asma.

Sejak Camargo dkk ${ }^{37}$ pertama kali menjelaskan hubungan antara obesitas dan asma, banyak penelitian epidemiologi dilaporkan selama dekade terakhir menunjukkan peningkatan risiko asma pada pasien yang obes. Obesitas telah dikaitkan dengan buruknya kontrol asma pada anakanak dan dewasa. ${ }^{38}$ Taylor $\mathrm{dkk},{ }^{39}$ melaporkan bahwa obesitas berhubungan dengan peningkatan gejala harian asma, kehilangan hari kerja, peningkatan penggunaan bronkodilator dan secara keseluruhan menurunnya derajat kontrol asma. Obesitas juga berhubungan dengan kurangnya kemungkinan mencapai kendali asma dengan baik dan respons yang kurang saat diterapi. ${ }^{40}$

Mekanisme yang mendasari hubungan antara obesitas dan asma belum sepenuhnya dipahami. Meskipun jalur mekanik, imunologi, genetik, hormonal, dan lingkungan telah dipikirkan sebagai jalur yang mendasari mekanisme asma pada obesitas. Sampai saat ini belum jelas dari berbagai jalur tersebut yang mana merupakan mekanisme yang dominan. Namun, diyakini bahwa inflamasi sistemik pada obesitas yang dimodifikasi oleh adipokin dan penanda inflamasi sistemik lainnya memainkan peranan yang penting.
Pemahaman lebih lanjut tentang mekanisme yang mendasari asma pada obesitas akan memiliki implikasi yangsignifikan. ${ }^{38}$

Lessard dkk, ${ }^{41}$ menunjukkan bahwa orang dewasa yang menderita asma dan obesitas memiliki profil fungsi paru yang berbeda dari mereka yang obes tanpa asma. Sebuah penelitian pada 2.715 anak usia sekolah di Yunani, itu menunjukkan bahwa fungsi paru pada anak obesitas berkurang di semua indeks spirometri seperti forced expiratory volume in 1 second $\left(\mathrm{FEV}_{1)}\right.$, forced vital capacity (FVC), dan rasio $\mathrm{FEV}_{1} / \mathrm{FVC}$. Statusgizitetapmenjadipenentuindependen menurunnya parameter spirometri dan faktor risiko untuk asma dan atopi. Hipotesis mengenaistatusgizimenurunkanfungsiparu melalui dua mekanisme yakni menurunnya mobilitas diafragma dan rongga dada serta meningkatnya sekresi sitokin inflamasi. ${ }^{42}$

Huang dkk, ${ }^{42}$ dalam studinya menunjukkan adanya peningkatan PAI1 pada pasien anak asma dengan obese dibandingkan dengan kontrol. Selanjutnya dalam studi tersebut peningkatan kadar PAI1 didapatkan pada anak dengan wheezing yang rekuren dibandingkan subyek kontrol, di mana didapatkan lebih tinggi pada anakyang sering mengalami relaps. Hal ini berbeda dengan hasil yang kami dapatkan dalam penelitian ini dimana analisis perbandingan kadar PAI-1 menurut derajat kontrol dan status gizi memperlihatkan bahwa hanya pada subyek dengan status gizi normal didapatkankadarPAI-1signifikanlebihtinggi pada asma tidak terkontrol dibandingkan yang terkontrol ( $\mathrm{p}<0,05)$, sedangkan subyek Obes tidak didapatkan perbedaan signifikan. Hal yang dapat menjelaskan tidak terdapatnya perbedaan yang signifikan kadar 
PAI-1 dengan derajat kontrol pada subyek asma dengan obes karena status obes sendiri dapat meningkatkan kadar PAI-1. Obesitas telah dikaitkan dengan perubahan dalam sistem hemostatik ditandai oleh aktivasi pembekuan dan fibrinolisis yang tidak semestinya. Fibrinogen merupakan faktor koagulasi sekaligus reaktan fase akut, dan PAI-1 merupakan inhibitor fisiologis yang paling penting pada fibrinolisis endogen. Selsel lemak bisa melepaskan sejumlah besar PAI-1, yang mungkin disebabkan olehinsulin. Oleh karena itu, dapat memberikan kontribusi yang signifikan terhadap peningkatan plasma PAI-1 pada sindrom resistensi insulin. ${ }^{43}$

\section{KESIMPULAN}

Kadar PAI-1 ditemukan lebih tinggi secara bermakna pada asma tidak terkontrol.

\section{SARAN}

1. Diharapkan agar para klinisi dapat lebih memahami proses remodeling pada saluran napas dan peranan PAI-1 dalam proses remodeling saluran napas penderita asma.

2. Adanyabuktiperanan PAI-1padaproses remodeling saluran napas dapat menjadi dasar pertimbangan dalam tindakan preventif dan penatalaksanaan pada penderita asma di masa mendatang.

\section{DAFTAR PUSTAKA}

1. FitzGerald JM, Reddel HK, Bateman $\mathrm{ED}$, et al. Global strategy for asthma management and prevention. GINA. National Health National Heart, Lung and Blood in Health (NIH) Publication: 2015. p.1-124.
2. Akinbami LJ, Moorman JE, Liu X. Asthma Prevalence, Health Care Use, and Mortality: United States, 2005-2009. National Health Statistics Reports 2011; 46: 1-15.

3. Syamsu. Seluk Beluk Asma. Sub Bagian Alergi Imunologi Departemen Ilmu Penyakit Dalam FKUnhas. 2014: 21-2.

4. Sundaru H, Sukamto. Alergi dan Imunologi Klinik. Buku Ajar Ilmu Penyakit Dalam. 6 ed. Jakarta: Interna Publishing; 2012. p.478-88.

5. Elias JA, Zhu Z, Chupp G, et al. Airway remodeling in asthma. J Clin Invest. 1999; 104: 1001-6.

6. Bergeron C, Al-Ramli W, Hamid Q. Remodeling in Asthma. Proc Am Thorac Soc 2009; 6: 301-5.

7. Boer JDd, Majoor CJ, Veer Cvt, et al. Asthma and coagulation. BLOOD.2012; 119: 3236-44.

8. Binder BR, Christ G, Gruber F, et al. Plasminogen Activator Inhibitor 1: Physiological and Pathophysiological Roles News Physiol Sci. 2002;17: 56-61.

9. Hermans PWM, Hazelzet JA. Plasminogen Activator Inhibitor Type 1 Gene PolymorphismandSepsis. Clin Infect Dis. 2005; 41(6): S453-8.

10. Cho SH, Tam SW, Demissie-Sanders S, et al. Production of Plasminogen Activator Inhibitor-1 by Human Mast Cells and Its Possible Role in Asthma. J Immunol 2000; 165: 3154-61;

11. Bernot D, Stalin J, Stocker P, et al. Plasminogen activator inhibitor 1 is an intracellularinhibitor offurin proprotein convertase. J Cell Sci. 2010; 124: 122430. 
12. Stewart CE, Nijmeh HS, Brightling CE, et al. UPAR regulates bronchial epithelial repair in vitro andiselevated in asthmatic epithelium. Am J Respir Cell Mol Biol 2006; 35: 503-11.

13. Margaglione M, Cappucci G, d'Addedda $\mathrm{M}$, et al. PAI-1 Plasma Levels in a General Population Without Clinical Evidence of AtherosclerosisRelationtoEnvironmental and Genetic Determinants. Arterioscler Thromb Vasc Biol. 1998; 18: 562-7.

14. Wagers SS, Norton RJ, Rinaldi LM, et al. Extravascular fibrin, plasminogen activator, plasminogen activator inhibitors, and airway hyperresponsiveness. J Clin Invest. 2004; 114: 104-11.

15. Swaisgood CM, Aronica MA, Swaidani $\mathrm{S}$, et al. Plasminogen Is an Important Regulatorin thePathogenesis of a Murine Model of Asthma.Am J Respir Crit Care Med 2007; 176: 333-42.

16. Cho SH, Hall IP, Wheatley A, et al. Possible role of the $4 \mathrm{G} / 5 \mathrm{G}$ polymorphism of the plasminogen activator inhibitor 1 gene in the development of asthma. J Allergy Clin Immunol. 2001; 108: 212-4.

17. Cho SH, Kang J, Lyttle C, et al. Elevated Plasma Levels Of Plasminogen Activator Inhibitor-1 Are Associated With Diminished Lung Function InAsthma. Ann Allergy Asthma Immunol. 2011; 106(5): 371-37.

18. Nie W, Li B, Xiu Q-y. The $26754 G / 5 G$ Polymorphism in Plasminogen Activator Inhibitor-1 Gene Is Associated with Risk of Asthma: A Meta-Analysis. plos one journal. 2012; 7:1-5.
19. Rasmussen F, Taylor DR, FlanneryEM, etal. Risk Factorsfor Airway Remodeling in Asthma Manifested by a Low Postbronchodilator FEV1 / Vital Capacity Ratio. A Longitudinal Population Study from ChildhoodtoAdulthood.AmJRespir Crit Care Med. 2002; 165: 1480-8.

20. Oemiati R, Sihombing M, Qomariah. Faktor-Faktor yang Berhubungan dengan Penyakit Asma di Indonesia. Jurnal Kesehatan Badan Penelitian dan Pengembangan Kesehatan. 2010; 20: 41-9.

21. Kemenkes RI. RISKESDAS 2013 Kementrian Kesehatan Republik Indonesia. Available at: htpp://www. depkes. go. id.41-9].

22. Berhane K, Mcconnell R, Gilliland F, et al. Sex-specific Effects of Asthma on Pulmonary Function in Children. Am J Respir Crit Care Med. 2000; 162: 172330.

23. Hashimoto $\mathrm{M}$, Tanaka $\mathrm{H}$, Abe S. Quantitative Analysis of Bronchial Wall Vascularity in the Medium and Small Airways of Patients With Asthma and COPD.CHEST.2005; 127(5): 965-72.

24. Walters EH, Soltani A, Reid DW, et al. Vascular remodelling in asthma. Curr Opin Allergy Clin Immunol. 2008; 8: 3943.

25. Oh CK. Mast Cell Mediators in Airway Remodeling. Chem Immunol Allergy. 2005; 87: 85-100.

26. Oh CK, Ariue B, Alban RF, et al. PAI-1 promotes extracellular matrix deposition in the airways of a murine asthma model. Biochem Biophys Res Commun. 2002; 294(5): 1155-60. 
27. Little SA, Sproule MW, Cowan MD, etal. High resolution computed tomographic assessment of airway wall thickness in chronic asthma: reproducibility and relationship with lung function and severity. Thorax.2002;57:247-53.

28. Liu R-M, Eldridge S, Watanabe N, et al. Therapeutic potential of an orally effective small molecule inhibitor of plasminogen activator inhibitor for asthma Am J Physiol Lung Cell Mol Physiol. 2016; 310: L328-L36.

29. Aikawa T, Shimura S, Sasaki H, et al. Marked Goblet Cell Hyperplasia with Mucus Accumulation in the Airways of Patients Who Died of Severe Acute Asthma Attack. Chest. 1992; 101(4): 916-21.

30. Lee SH, Eren M, Vaughan DE, et al. A Plasminogen Activator Inhibitor-1 Inhibitor Reduces Airway Remodeling in a Murine Model ofChronic Asthma.Am J RespirCell Mol Biol 2012;46(6):842-6.

31. Bora E, Soylarc R, Arıkan-Ayyıldız Z, et al. Plasminogen activator inhibitor-1 and angiotensin converting enzymegene polymorphisms in Turkish asthmatic children. J Aller. 2013; 41: 11---6.

32. Hoshino M, Takahashi M, Aoike N. Expression of vascular endothelial growth factor, basic fibroblast growth factor, and angiogenin immunoreactivity in asthmatic airways andits relationship to angiogenesis. J Allergy Clin Immunol. 2001; 107(2): 295-301.

33. Ma Z, Paek D, Oh CK. Plasminogen activator inhibitor-1 and asthma: role in the pathogenesis and molecular regulation. Clin Exp Allergy. 2009; 39(8): 1136-44.
34. Detoraki A, Granata F, Staibano S, et al. Angiogenesis and lymphangiogenesis in bronchial asthma. Allergy. 2010; 65: 946-58.

35. Cesary M, Pahor M, Incalzi RA, Plasminogen Activator Inhibitor-1 (PAI1): A Key Factor Linking Fibrinolysis and Age-Related Subclinical and Clinical Conditions. CardiovascularTherapeutics. 2010; 28: 72-81.

36. Yamamotoa $\mathrm{K}$ et al, Aging and Plasminogen Activator Inhibitor-1 (PAI-1) Regulation: Implication in The Pathogenesis of Thrombotic Disorders in The Elderly.J.cardiores. 2005; 66:276285.

37. Camargo CA, Weiss ST, Zhang S, et al. Prospective Study of Body Mass Index, Weight Change, and Risk of Adult-onset Asthma in Women. Arch Intern Med. 1999; 159(21): 2582-8.

38. Ali Z, Ulrik CS. Obesity and asthma:A coincidence or a causal relationship? A systematic review. Res Med. 2013; 20:114.

39. Taylor B, Mannino D, Brown C, et al. Body mass index and asthma severity in the National Asthma Survey. Thorax. 2008; 63(1): 14-20.

40. Camargo CA, Sutherland ER, Bailey W, et al. Effect of increased body mass index onasthmarisk,impairmentandresponse to asthma controller therapy in African Americans. Curr Med Res Opin. 2010; 26(7): 1629-35.

41. Lessard A, Turcotte H, Cornier Y, et al. Obesity and Asthma. A Specific Phenotype?CHEST.2008;134:317-23. 
42. Huang F, del-Río-Navarro BE, Alcántara ST, et al. Plasminogen Activator Inhibitor-1, Fibrinogen, and Lung Function in Adolescents with Asthma and Obesity. Endocr Res. 2012; 37(3): 13544 .

43. Oh CK, Ariue B, Alban RF, et al. PAI-1 promotes extracellular matrix deposition in the airways of a murine asthma model. Biochem Biophys Res Commun. 2002; 294(5): 1155-60. 